\title{
Valósághú páciensszimulátorok alkalmazása a hallgatói teljesítmény értékelésében
}

\author{
Borján Eszter ${ }^{1}$ - Mészáros Judit dr. ${ }^{2}$ - Rigó János Jr. dr. ${ }^{1,3}$ \\ Semmelweis Egyetem, ${ }^{1}$ Egészségtudományi Kar, Szülészeti és Nőgyógyászati Klinikai Ismeretek Tanszék, \\ ${ }^{2}$ Egészségtudományi Kar, ${ }^{3}$ Általános Orvostudományi Kar, I. Szülészeti és Nőgyógyászati Klinika, Budapest
}

\begin{abstract}
Bevezetés: A Semmelweis Egyetem Egészségtudományi Karán 2007 óta alkalmaznak valósághư szimulátorokat. Célkitüzés: A szerzők célul tűzték ki a hallgatók ismereteinek, készségeinek felmérését a szimulációs kurzusok befejezését követően. Módszer: A C-SEI elnevezésű validált értékelőlap segítségével történő adatfelvételre a szülésznőhallgatók felmérése során került sor, a „Klinikai szimuláció” kurzus után 67 fő részvételével, a „Szimulációs esettanulmányok” kurzust követóen 58 fő bevonásával. Eredmények: A „Klinikai szimuláció” kurzust követően a hallgatók által elért

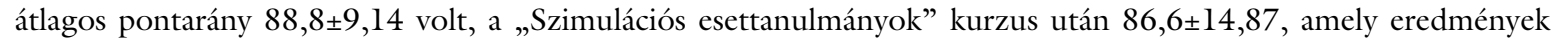
szignifikánsan magasabbak a minimálisan elvárt 75-höz viszonyítottan $(\mathrm{p}<0,01)$. Az értékelőlap alcsoportjai közül mindkét kurzust követően a kritikus gondolkodás esetén mutatkozott a legalacsonyabb átlageredmény. Az „Általános ápolástan” tantárgy vizsgája során kapott osztályzatok és a „Szimulációs esettanulmányok” kurzus utáni eredmények között közepes erôsségú, pozitív, szignifikáns összefüggést találtak $(\mathrm{r}=0,34 ; \mathrm{p}<0,01)$. Következtetések: A valósághü páciensszimulátorok alkalmazása megbízható és validált értékelőlap egyidejű használatával megfelelő módszer lehet a hallgatók értékelésére. Orv. Hetil., 2015, 156(33), 1335-1340.
\end{abstract}

Kulcsszavak: páciensszimulátor, szimulációs oktatás, hallgatói teljesítmény, értékelés

\section{Use of high-fidelity simulators for students' evaluation}

Introduction: The authors started to use high-fidelity simulators at Semmelweis University, Faculty of Health Sciences in September, 2007. Aim: The aim of this study was to evaluate the students' performance in order to determine their knowledge after each simulation course. Method: The Creighton Simulation Evaluation Instrument (C-SEI) was used to evaluate midwifery students' performance during examinations. 67 midwifery students were evaluated after the "Clinical simulation" course and 58 midwifery students after the "Case studies in simulation" course. Results: The average total scores were significantly higher than the desired level of $75(\mathrm{p}<0.01)$; after the "Clinical simulation" $88.8 \pm 9,14$, and after the "Case studies in simulation" courses $86.6 \pm 14.87$. Among subscales the lowest average total score was found in critical thinking in each of the course. Statistically significant correlation was found between the results of "General nursing care" and the results of "Case studies in simulation" courses $(\mathrm{r}=0.34 ; \mathrm{p}<0.01)$. Conclusions: The use of high-fidelity simulators with valid tools simultaneously might be a suitable method for students' evaluation.

Keywords: patient simulator, simulation education, students' performance, evaluation

Borján, E., Mészáros, J., Rigó, J. Jr. [Use of high-fidelity simulators for students' evaluation]. Orv. Hetil., 2015, $156(33), 1335-1340$.

(Beérkezett: 2015. június 5.; elfogadva: 2015. június 25.)

\section{Rövidítések}

C-SEI = Creighton Simulation Evaluation Instrument; HPS = human patient simulator; ECS = emergency care simu-

lator; METI = Medical Education Technologies, Inc.; $r$ = Pearson-féle korrelációs együttható 
A különböző szimulációs oktatási eszközök alkalmazása az egészségügyi szakemberek képzésében régóta ismert. A statikus modellek mellett az utóbbi 20 évben megjelentek a valósághư páciensszimulátorok, amelyek használata új oktatási módszerek kidolgozását tette szükségessé. Ezek a korszerű eszközök alkalmasak a különböző életjelenségek modellezésére, emellett képesek reagálni a beavatkozásokra (például gyógyszerek, folyadék, oxigén adására) az élő emberhez hasonlóan. A szimulációs oktatás legfőbb előnye a kockázatmentes gyakorlás életszerú környezetben, komplex esetek bemutatásával. További előnyei között szerepel: a ritka, illetve magas kockázatú esetek megismertetése, a manuális készségek fejlesztésének lehetősége, a kritikus gondolkodási képesség gyakoroltatása, a kommunikációs készség fejlesztése, illetve a hallgatók önbizalomszintjének növelése. A szimulációs oktatás gyakorlata közvetett módon a betegbiztonságot szolgálja, ezért használata napjainkban elengedhetetlenül fontos mind a graduális, mind pedig a posztgraduális oktatás területén az egészségügyi szakemberek képzése során $[1,2,3,4,5,6,7,8]$.

A Semmelweis Egyetem Egészségtudományi Karán az oktatásban 2007 szeptembere óta alkalmazunk valósághû szimulátorokat. A graduális képzésekbe 2009-től önálló tantárgyként vezettük be a szimulációt. Így került oktatásra a „Klinikai szimuláció" kurzus valamennyi szakirányon, valamint a „Szimulációs esettanulmányok” kurzus azon szakirányokon, ahol szükségesnek tartottuk a szakspecifikus szimuláció bevezetését, a legfontosabb esetek bemutatásával. A tantárgyak beillesztésének célja az volt, hogy a klinikai gyakorlatot előzze meg egy olyan demonstrációs tantermi gyakorlat, amely biztonságos környezetben készíti fel a hallgatókat a betegek alapvető észlelésére, a leggyakoribb problémák felismerésére és a segítségnyújtás legfontosabb lépéseire. Az egészségügyi szakemberek képzése során ezen új oktatási eszköz használata számos előnyt hordoz, mivel a betegmegfigyelés mellett különböző tevékenységek, beavatkozások kivitelezésére is lehetőséget nyújt.

A megszerzett tudás felmérésének, értékelésének az oktatás minden területén kiemelten fontos szerepe van. Az egészségügyi szakembereknek olyan komplex tudással kell rendelkezniük, amelynek mérése bonyolult és összetett feladat. A hagyományos képzési formákban az elméleti ismeretek és a gyakorlati készségek értékelése általában elkülönülten történik. A szimulációs tantermi gyakorlatok során alkalmazott mérés komplexitása hasonló a klinikai területeken végzett feladatok megítéléséhez. A szimuláció ezért alkalmas módszer lehet az elméleti tudás és a gyakorlati készségek egyidejű felmérésére $[9,10]$.

A klinikai gyakorlat komplexitásának növekedésével a validált és megbízható értékelési módszerek egyre nagyobb szerepet játszanak a képzés során $[11,12,13$, $14]$.

Vizsgálatunk célja volt a páciensszimulátoron végzett vizsga során a hallgatók felkészültségének felmérése, az elvárt ismeretek, készségek értékelése az adott kurzusok befejezését követően. Jelen közleményben a szülésznő szak hallgatóinak vizsgálata során kapott eredményeket kívánjuk bemutatni és elemezni.

\section{Módszer}

A vizsgálatot a Semmelweis Egyetem Egészségtudományi Karán, 2013 decemberében végeztük a „Klinikai szimuláció” kurzus után, 67 fő szülésznőhallgató részvételével, valamint 2014 májusában ugyanazon hallgatói csoportnál, a „Szimulációs esettanulmányok” kurzust követően, 58 fő bevonásával. A „Klinikai szimuláció” kurzus (24 óra) során a leggyakoribb belgyógyászati és sebészeti „esetekkel” találkoznak a hallgatók a képzés harmadik szemeszterében. Ezzel párhuzamosan folyt a vizsgálat idején az „Általános ápolástan” tantárgy oktatása, amely szorosan kapcsolódik a szimulációs gyakorlatokhoz. A „Klinikai szimuláció” teljesítését követően, a képzés negyedik szemeszterében vettek részt a hallgatók a „Szimulációs esettanulmányok” kurzuson (12 óra), ahol szülészeti „esetek” bemutatására került sor az órákon. Mindkét szimulációs kurzus megelőzte a területi szakmai gyakorlatot, tehát a kutatásban részt vevő hallgatók valódi klinikai tapasztalattal nem rendelkeztek a vizsgálat idején.

A vizsga során a hallgató írásban kap egy esetleírást a „páciensről”. Feladata a betegmegfigyelés, az összegyưjtött információk, a mért paraméterek értékelése, dokumentálása, a kóros értékek felismerése esetén következtetés a lehetséges okokra, valamint a további teendők meghatározása. Az értékelés során célunk a betegmegfigyelés és ápolási feladatok szabályos kivitelezése mellett az aktuális tudásszint felmérése, továbbá a kritikus gondolkodási képesség és az adekvát helyzetfelismerés meglétének értékelése. Ennek megvalósítása érdekében a vizsgáztató (oktató) a gyakorlati tevékenység megfigyelése után kérdéseket tesz fel a hallgatónak és értékeli válaszait.

A szakirodalom részletes tanulmányozása során választottuk ki a Creighton University, School of Nursing (Amerikai Egyesült Államok) által kifejlesztett „Creighton Simulation Evaluation Instrument” (C-SEI) elnevezésű, validált vizsgálómódszert, mert ez ígérkezett saját gyakorlatunk számára a legmegfelelőbbnek. Használatára 2013 nyarán kaptunk engedélyt az értékelőlap fejlesztőitől, és annak magyar nyelvre történő lefordítása után kezdtük használni azt gyakorlatunkban. A módszer megbízhatóságának mérésére a Cronbach-féle alfa (megbízhatósági koefficiens) mutatót alkalmaztuk, amely saját vizsgálatunkban 0,818 volt. A Creighton Simulation Evaluation Instrument (C-SEI) használatával 22 szempont alapján értékelhető a hallgatók teljesítménye. Ennek adatlapját az 1. táblázat szemlélteti. A 22 szempont 4 alcsoporton belül (megfigyelés-adatgyújtés, kommunikáció, kritikus gondolkodás, technikai készségek) jelenik meg. Az egyes tevékenységek értékelése 0 vagy 1 ponttal 
Creighton Simulation Evaluation Instrument (C-SEI) - értékelőlap

\begin{tabular}{|c|c|c|}
\hline Megfigyelés, adatgyüjtés & \multicolumn{2}{|c|}{ Pontszám } \\
\hline 1. A páciens szubjektív adatainak összegyújtése & 0 & 1 \\
\hline 2. A páciens objektív adatainak összegyújtése & 0 & 1 \\
\hline $\begin{array}{l}\text { 3. További megfigyelés, adatgyüjtés szükségességének } \\
\text { felismerése }\end{array}$ & 0 & 1 \\
\hline $\begin{array}{l}\text { 4. Az adatgyüjtés szisztematikus, rendezett, megfelelő } \\
\text { technikával történő végzése }\end{array}$ & 0 & 1 \\
\hline \multicolumn{3}{|l|}{ Kommunikáció } \\
\hline 5. Hatékony kommunikáció a teamtagokkal & 0 & 1 \\
\hline 6. Hatékony kommunikáció a pácienssel & 0 & 1 \\
\hline 7. A dokumentáció világos, érthető, pontos vezetése & 0 & 1 \\
\hline 8. Megfelelő reagálás a kóros értékekre, eredményekre & 0 & 1 \\
\hline 9. Valósághű, szakszerú viselkedés & 0 & 1 \\
\hline \multicolumn{3}{|l|}{ Kritikus gondolkodás } \\
\hline $\begin{array}{l}\text { 10. A vitális paraméterek (testhőmérséklet, pulzus, } \\
\text { vérnyomás, légzésszám, fájdalom) értelmezése }\end{array}$ & 0 & 1 \\
\hline 11. Laboreredmények értelmezése & 0 & 1 \\
\hline $\begin{array}{l}\text { 12. Szubjektív/objektív adatok értelmezése (releváns } \\
\text { adatok felismerése) }\end{array}$ & 0 & 1 \\
\hline 13. Mérhető kimenetel megfogalmazása & 0 & 1 \\
\hline 14. Kimenetel-vezérelt beavatkozások végzése & 0 & 1 \\
\hline $\begin{array}{l}\text { 15. Specifikus, ésszerű magyarázat adása a } \\
\text { beavatkozásokra }\end{array}$ & 0 & 1 \\
\hline 16. A beavatkozások és a kimenetel értékelése & 0 & 1 \\
\hline 17. Reflektálás a szimulációs gyakorlatra & 0 & 1 \\
\hline \multicolumn{3}{|l|}{ Technikai készségek } \\
\hline 18. A páciens azonosításának elvégzése & 0 & 1 \\
\hline 19. A standard óvintézkedések, előírások alkalmazása & 0 & 1 \\
\hline 20. Biztonságos gyógyszerelés & 0 & 1 \\
\hline 21. Az eszközök megfelelő használata & 0 & 1 \\
\hline 22. A beavatkozások megfelelő kivitelezése & 0 & 1 \\
\hline
\end{tabular}

Creighton University, School of Nursing, Omaha, Nebraska engedélyével.

történik. A maximálisan elérhető pontszám 22 (100\%). Elvártnak tekintettük a legalább 75\%-os pontarány teljesítését, az értékelőlap kifejlesztőinek ajánlása alapján [15, 16]. Az oktatók előzetesen meghatározták az adott szemponthoz tartozó elvárásokat.

A hallgatói munka értékelése a vizsga közben valósult meg (az adatlap oktatók általi kitöltésével), majd a videóra rögzített anyag elemzése során újraértékeltük teljesítményüket. A videóra történő rögzítéshez a hallgatók írásbeli beleegyezésüket adták. A vizsgálathoz a METI (Medical Education Technologies, Inc.) cég által gyártott HPS6 ECS (Human Patient Simulator - Emergency Care Simulator) modellt használtuk. A vizsga hallgatónként átlagosan 20 percig tartott.
Az értékelőlap megbízhatóságának meghatározása a Cronbach-féle alfa (megbízhatósági koefficiens) mutató számításával történt $(0,818)$. A hallgatói csoportok átlageredményeinek az elvárt értéktől való eltérését az egymintás T-próbával vizsgáltuk. Az összefüggésvizsgálat során a Pearson-féle korrelációs együtthatót alkalmaztuk. A statisztikai analízis az IBM SPSS Statistics 22 program segítségével történt. A szignifikancia szintjét $\mathrm{p}<0,01$ értéken határoztuk meg.

\section{Eredmények}

Elsőként a csoportok átlageredményeit határoztuk meg a két kurzust („Klinikai szimuláció” és „Szimulációs esettanulmányok”) követően. Mindkét kurzus után szignifikánsan magasabb eredmény mutatkozott a minimálisan elvárt pontarányhoz $(75 \%)$ viszonyítva $(\mathrm{p}<0,01)$. A „Klinikai szimuláció” kurzust követő vizsgán a szülésznőhallgatók által elért átlagos pontarány $88,8 \pm 9,1$ volt. A „Szimulációs esettanulmányok” kurzus után a hallgatók átlagos eredménye 86,6 1 14,8 volt.

A továbbiakban a hallgatók egyéni teljesítményét vizsgáltuk kurzusonként. A „Klinikai szimuláció” kurzus eredményeit az 1. ábra szemlélteti. A hallgatók teljesítménye viszonylag egyenletes volt, a 67 fóből összesen 7 (10,4\%) nem érte el a minimális 75\%-ot. Kiugróan alacsony eredményt egy hallgatónál sem tapasztaltunk. 15 hallgató $(22,3 \%)$ kiemelkedően jól teljesített, 95\% feletti pontarányt elérve.

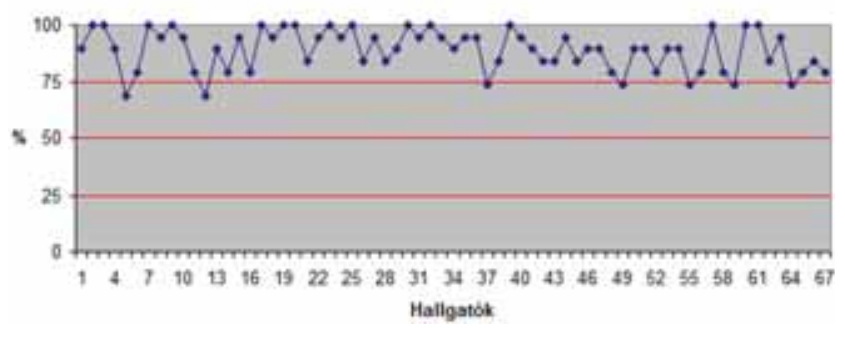

1. ábra | A szülésznőhallgatók eredményei a „Klinikai szimuláció” kurzus után $(\mathrm{N}=67)$

Érdemesnek tartottuk megvizsgálni, hogy az értékelőlap 4 alcsoportja (megfigyelés-adatgyưjités, kommunikáció, kritikus gondolkodás, technikai készségek) közül mely esetben találjuk a legalacsonyabb átlagértéket. Az eredményeket a 2. táblázat mutatja be.

A megfigyelés-adatgyüjtés alcsoportnál a pontarány $87,6 \pm 18,1$, a kommunikáció területén $89,5 \pm 15,8$, a technikai készségeknél $88,8 \pm 17,6$ volt. A legalacsonyabb átlageredmény a „kritikus gondolkodás” alcsoportnál mutatkozott: $85,1 \pm 15,5$.

A „Szimulációs esettanulmányok” kurzusnál szintén a hallgatók egyéni eredményeit vizsgáltuk (2. ábra). A hallgatók kevésbé kiegyensúlyozott teljesítményt mutattak a „Klinikai szimuláció” kurzushoz képest. 14 hallga- 
2. táblázat |A „Klinikai szimuláció” kurzus alcsoportonkénti átlagértékei a szülésznőhallgatóknál $(\mathrm{N}=67)$

\begin{tabular}{ll}
\hline Alcsoport & Átlag \pm SD \\
\hline Megfigyelés, adatgyújtés & $87,6 \pm 18,1$ \\
Kommunikáció & $89,5 \pm 15,8$ \\
Kritikus gondolkodás & $85,1 \pm 15,5$ \\
Technikai készségek & $88,8 \pm 17,6$ \\
\hline
\end{tabular}

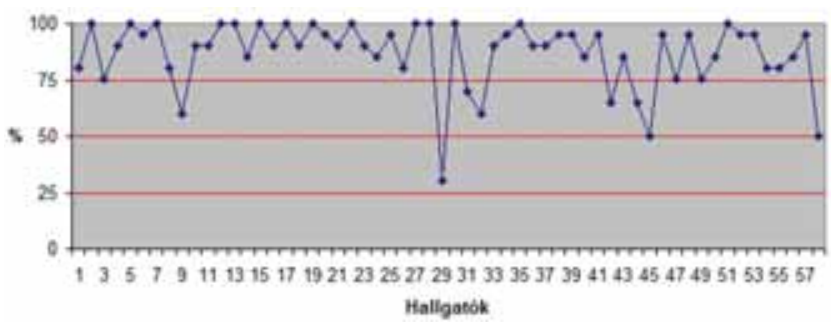

2. ábra

A szülésznőhallgatók eredményei a „Szimulációs esettanulmányok" kurzus után $(\mathrm{N}=58)$

tó $(24,1 \%)$ kiváló (95\% feletti) eredményt ért el. Az 58 hallgató közül 8 fó (13,8\%) nem érte el a minimális 75\%ot. Három hallgató extrém alacsony ( $50 \%$ vagy ez alatti) pontarányt ért el. Az alcsoportonkénti átlageredményeket a 3. táblázatban mutatjuk be.

A megfigyelés-adatgyújités alcsoportnál a pontarány $87,5 \pm 24,0$, a kommunikáció területén $89,6 \pm 18,1$, a technikai készségeknél 92,1 1 12,4 volt. A legalacsonyabb átlageredményt itt is a „kritikus gondolkodás” alcsoportnál kaptuk: 80,3 $\pm 18,1$.

Bár a két kurzus során elért átlagos pontarány csak minimális eltérést mutatott, magyarázatot kerestünk a „Szimulációs esettanulmányok" kurzus során, a három hallgató esetén tapasztalt kiugróan alacsony teljesítmény hátterére. A „Szimulációs esettanulmányok” vizsga esetén már elvárt az „Általános ápolástan” tantárgyban tanult készségek és képességek bemutatása, ezért arra kerestünk választ, hogy van-e összefüggés a „Szimulációs esettanulmányok" értékelésekor kapott eredmények és az „Általános ápolástan” tantárgy vizsgáján elért osztályzatok között.

A „Szimulációs esettanulmányok” kurzus utáni átlagos eredmény $(86,6 \pm 14,8)$ és az „Általános ápolástan” tantárgy osztályzatainak átlaga $(4,2 \pm 0,8)$ közötti össze-

3. táblázat A „Szimulációs esettanulmányok” kurzus alcsoportonkénti átlagértékei a szülésznőhallgatóknál $(\mathrm{N}=58)$

\begin{tabular}{ll}
\hline Alcsoport & Átlag \pm SD \\
\hline Megfigyelés, adatgyújtés & $87,5 \pm 24,0$ \\
Kommunikáció & $89,6 \pm 18,1$ \\
Kritikus gondolkodás & $80,3 \pm 18,1$ \\
Technikai készségek & $92,1 \pm 12,4$ \\
\hline
\end{tabular}

függést és annak erősségét a Pearson-féle korrelációs együttható segítségével vizsgáltuk. Az „Általános ápolástan” tantárgy vizsgáján szerzett osztályzatok és a „Szimulációs esettanulmányok" kurzus utáni eredmények között közepes erôsségű, pozitív, szignifikáns összefüggést találtunk $(\mathrm{r}=0,34 ; \mathrm{p}<0,01)$.

\section{Megbeszélés}

A páciensszimulátorok oktatásban való alkalmazásának kezdetén a hallgatói elégedettséget, az önbizalomszint változását vizsgálták, de ezen kutatások nem adtak átfogó és értékelhető eredményeket a szimulációs gyakorlatok hatásáról a képzés során. A megbízható és validált értékelési módszerek használata egyre nagyobb szerepet játszik a szimulációs oktatás során [9]. Saját gyakorlatunkban a Creighton University, School of Nursing (Amerikai Egyesült Államok) által kidolgozott, C-SEI (Creighton Simulation Evaluation Instrument) elnevezésű értékelőlapot kezdtük használni a 2013/14-es tanévtôl a szimulációs kurzusokat követő vizsgáztatás során.

A szakirodalomban kevés közlemény foglalkozik a C-SEI értékelőlap használatával kapott eredmények ismertetésével. Az egyik vizsgálatban 24 ápolóhallgató vett részt, ahol a 4 fós csoportok teljesítményét mérték. A 6 csoportból 4 érte el a minimálisan meghatározott 75\%-ot [17]. Egy másik kutatásban a videóra rögzített szimuláció segítségével történő tanulás hatását vizsgálták (54 ápoló esetén), ahol a hallgatók teljesítményének értékelésére szintén a C-SEI-t használták. A szimulációs gyakorlatokat kiegészítették egy videóra rögzített szimuláció bemutatásával. A videó bemutatása előtt és azt követően is felmérték a hallgatók tudását a C-SEI értékelőlap segítségével. A hallgatók teljesítménye szignifikánsan javult a megfigyelés-adatgyưjjtés, kommunikáció, kritikus gondolkodás és a technikai készségek terén [18]. A C-SEI kifejlesztői a hallgatókat megfigyelő oktatók közötti egységes értékelési stratégia kidolgozását tartották kiemelten fontosnak, és az ezzel kapcsolatos vizsgálatok eredményeit több közleményben is bemutatták [14, 15, 16]. Saját kutatásunkhoz hasonló vizsgálatot eddig nem közöltek.

Vizsgálatunk során a C-SEI értékelőlap 22 szempontja alapján mértük fel a hallgatók vizsgán nyújtott teljesítményét és értékeltük a csoportok átlageredményeit. A vizsgák során, mindkét kurzus esetén, szignifikánsan jobb átlageredmény mutatkozott a 75\%-os elvárt értékhez viszonyítva.

A hallgatók egyéni pontszámainak tekintetében már nem volt teljesen kedvező a helyzet. A „Klinikai szimuláció" kurzusnál ugyan egyenletes teljesítmény mutatkozott a hallgatói csoportnál, de voltak olyan tanulók, akik nem érték el a minimális, 75\%-os szintet. A „Szimulációs esettanulmányok kurzusnál” is közel azonos arányú volt azon hallgatók száma, akik nem teljesítették a minimális követelményt, illetve előfordultak kiugróan gyenge teljesítményü hallgatók is. A sikertelen szimulációs gyakorlat 
azt jelenti, hogy a hallgató nem rendelkezik az elvárt kompetenciával, amely a vizsgálati módszer jellemzőit figyelembe véve komoly hiányosságokra mutat rá. Ezeknek a hallgatóknak a vizsgát természetesen meg kellett ismételniük. Az ismételt vizsgát mindannyian sikeresen teljesítették.

A sikertelen szimuláció hátterének feltárása érdekében vizsgáltuk, hogy van-e összefüggés az „Általános ápolástan” tantárgy vizsgáján nyújtott teljesítmény és a „Szimulációs esettanulmányok” kurzus utáni eredmények között. A két tantárgy tananyagtartalma között szoros összefüggés van. Az „Általános ápolástan” tantárgyban elsajátított készségek, képességek a vizsgát követően először a „Szimulációs esettanulmányok” kurzus utáni értékeléskor kerülnek számonkérésre. A Pearson-féle korrelációs együttható meghatározásával közepes erősségű, pozitív, szignifikáns összefüggést találtunk a két tantárgyban nyújtott teljesítmény között. A gyengén teljesítő hallgatók eredményeinek vizsgálatakor látható volt, hogy ők az „Általános ápolástan” tantárgyban is rosszabbul teljesítettek társaiknál.

A készségek, képességek kialakításához azonban nem elég a szimulációs gyakorlatok során szerzett tapasztalat. Azok megerősítésére elengedhetetlenül fontos a valódi klinikai gyakorlat és az ott szerzett tapasztalat. Ennek elősegítése érdekében változtattunk a tantárgyak curriculumban elfoglalt helyén. A „Klinikai szimuláció” kurzus a képzés harmadik szemeszteréről a negyedikre került, míg a „Szimulációs esettanulmányok” tantárgyat a képzés hatodik félévére helyeztük át. A változtatástól a későbbiekben kiegyensúlyozottabb hallgatói teljesítményt várunk.

Mindkét kurzus esetén (külön-külön) vizsgáltuk az alcsoportok (megfigyelés-adatgyüjtés, kommunikáció, kritikus gondolkodás, technikai készségek) szerinti átlagértékeket annak feltárása érdekében, hogy képet kapjunk azon területekről, amelyeket esetleg nagyobb mértékben szükséges fejlesztenünk a gyakorlatok során. Az alcsoportok átlageredményeinél - mindkét kurzus esetén látható, hogy a kapott pontarány $80 \%$ felett van. A „Szimulációs esettanulmányok" kurzus esetén a technikai készségek terén a hallgatók kiemelkedően jól teljesítettek, míg a kritikus gondolkodás esetén mutatkozott a legalacsonyabb átlegeredmény mindkét kurzust követően. Ez az eltérés azt mutatja, hogy a kritikus gondolkodás jelentette számukra a legnagyobb nehézséget. A kritikus gondolkodás egy adott jelenségnek vagy szituációnak tervszerü, önirányított értékelését jelenti, tehát alapvető jelentőségű az egészségügyi szakemberek mindennapi gyakorlatában $[19,20]$. Ezen készség kialakulásához azonban idő és megfelelő tapasztalat szükséges. Vizsgálatunkban olyan hallgatók vettek részt, akik valódi klinikai gyakorlattal nem rendelkeztek, tehát érthető, hogy a kritikus gondolkodás területén kevésbé teljesítettek jól, mint a többi vizsgált alcsoportban. A szimulációs gyakorlatok azonban kiváló lehetőséget nyújthatnak ezen készség gyakorlására a képzés során.
A valósághű páciensszimulátorok alkalmazásáról megállapítható, hogy egy megbízható és validált értékelőlap egyidejü használatával megfelelő módszer lehet a hallgatói teljesítmények értékelésében az egészségügyi szakemberek képzése során [21, 22]. Kutatási eredményeink alapján elmondható, hogy a Creighton Simulation Evaluation Instrument (C-SEI) saját gyakorlatunkban is jól alkalmazható. Lehetőséget nyújt a szimulációs kurzusokat követően a hallgatók objektív értékelésére a megfigyelés-adatgyújtés, kommunikáció, technikai készségek, valamint a kritikus gondolkodás terén, az aktuális tudásszint figyelembevételével. Az értékelőlap szempontjainak komplexitásából adódóan a hallgatói tudás, valamint a különböző készségek és képességek mérése hasonlóan történhet, mint a valódi klinikai környezetben. Fontosnak tartjuk azonban a jelenlegi két szimulációs kurzus mellett a szimulációs gyakorlatok folyamatos jelenlétét a képzés során, az egészségügyi szakemberek számára fontos készségek és képességek kialakítása, valamint további fejlesztése érdekében. A kritikus gondolkodási készség mérése további vizsgálatokat igényel. Fejlesztésére még nagyobb hangsúlyt kell fektetnünk a képzés során.

Anyagi támogatás: A közlemény megírása anyagi támogatásban nem részesült.

Szerzôi munkamegosztás: B. E.: Szakirodalmi rész feldolgozása, kutatási cél meghatározása, a vizsgálat lefolytatása, a statisztikai elemzések elvégzése, ábrák és táblázatok elkészítése, a kézirat megszövegezése. M. J.: Szakmai áttekintés. R. J. Szakmai áttekintés, a kézirat megszövegezése. A cikk végleges változatát mindhárom szerző elolvasta és jóváhagyta.

Érdekeltségek: A szerzőknek nincsenek érdekeltségeik.

\section{Irodalom}

[1] Issenberg, S. B., McGaghie, W. C., Hart, I. R., et al.: Simulation technology for health care professional skills training and assessment. JAMA, 1999, 282(9), 861-866.

[2] Jeffries, P. R.: A framework for designing, implementing, and evaluating simulations used as teaching strategies in nursing. Nurs. Educ. Perspect., 2005, 26(2), 96-103.

[3] Bradley, P.: The history of simulation in medical education and possible future directions. Med. Educ., 2006, 40(3), 254-262.

[4] Kuznar, K. A.: Associate degree nursing students' perceptions of learning using a high-fidelity human patient simulator. Teach. Learn. Nurs., 2007, 2(2), 46-52.

[5] Schiavenato, M.: Reevaluating simulation in nursing education: beyond the human patient simulator. J. Nurs. Educ., 2009, $48(7), 388-394$.

[6] Ganley, B. J., Linnard-Palmer, L.: Academic safety during nursing simulation: perceptions of nursing students and faculty. Clin. Sim. Nurs., 2012, 8(2), e49- e57.

[7] Lewis, R., Strachan, A., Smith, M. M.: Is high fidelity simulation the most effective method for the development of non-technical skills in nursing? A review of the current evidence. Open Nurs. J., 2012, 6, 82-89. 
[8] Mompoint-Williams, D., Brooks, A., Lee, L., et al.: Using high-fidelity simulation to prepare advanced practice nursing students. Clin. Sim. Nurs., 2014, 10(1), e5-e10.

[9] Kardong-Edgren, S., Adamson, K. A., Fitzgerald, C.: A review of currently published evaluation instruments for human patient simulation. Clin. Sim. Nurs., 2010, 6(1), e25-e35.

[10] Scalese, R. J., Hatala, R.: Competency assessment. In: Levine, A I., DeMaria, Jr. S., Schwartz, A. D., et al. (eds.): The comprehensive textbook of healthcare simulation. Springer Science+Business Media, New York, 2013.

[11] Scalese, R. J., Obeso, V. T., Issenberg, S. B.: Simulation technology for skills training and competency assessment in medical education. J. Gen. Intern. Med., 2008, 23(Suppl. 1), 46-49.

[12] Adamson, K. A.: Assessing the reliability of simulation evaluation instruments used in nursing education: a test of concept study. Dissertation. Washington State University, 2011.

[13] Robinson, B. K., Dearmon, V.: Evidence-based nursing education: effective use of instructional design and simulated learning environments to enhance knowledge transfer in undergraduate nursing students. J. Prof. Nurs., 2013, 29(4), 203-209.

[14] Adamson, K. A., Kardong-Edgren, S., Willhaus, J.: An updated review of published simulation evaluation instruments. Clin. Sim. Nurs., 2013, 9(9), e393-e400.

[15] Todd, M., Manz, J. A., Hawkins, K. S., et al.: The development of a quantitative evaluation tool for simulations in nursing education. Int. J. Nurs. Educ. Scholarsh., 2008, 5(1), 1-17.
[16] Parsons, M. E., Hawkins, K. S., Hercinger, M., et al.: Improvement in scoring consistency for the Creighton Simulation Evaluation Instrument. Clin. Sim. Nurs., 2012, 8(6), 233-238.

[17] Patton, S. K.: A tool to evaluate simulations in nursing education. Thesis. University of Arkansas, 2011.

[18] Sharpnack, P. A., Goliat, L., Baker, J. R., et al.: Thinking like a nurse: Using video simulation to rehearse for professional practice. Clin. Sim. Nurs., 2013, 9(12), e571-e577.

[19] Shinnick, M. A., Woo, M. A.: The effect of human patient simulation on critical thinking and its predictors in prelicensure nursing students. Nurse Educ. Today, 2013, 33(9), 1062-1067.

[20] Shin, H., Ma, H., Park, J., et al.: The effect of simulation courseware on critical thinking in undergraduate nursing students: multi-site pre-post study. Nurse Educ. Today, 2015, 35(4), 537542 .

[21] Mikasa, A. W., Cicero, T. F., Adamson, K. A.: Outcome-based evaluation tool to evaluate student performance in high-fidelity simulation. Clin. Sim. Nurs., 2013, 9(9), e361-e367.

[22] Boese, T., Cato, M., Gonzalez, L., et al.: Standards of best practice: simulation standard V: facilitator. Clin. Sim. Nurs., 2013, 9(6 Suppl.), S22-S25.

(Borján Eszter,

Budapest, Vas u. 17., 1088 e-mail: eborjan@gmail.com)

\section{Tisztelt Szerzőink, Olvasóink!}

Az Orvosi Hetilapban megjelenő/megjelent közlemények elérhetőségére több lehetőség kínálkozik.

Rendelhetö különlenyomat, melynek áráról bővebben a www.akkrt.hu honlapon (Folyóirat Szerzöknek, Különlenyomat menüpont alatt) vagy Szerkesztőségünkben tájékozódhatnak.

A közlemények megvásárolhatók pdf-formátumban is, illetve igényelhetö Optional Open Article (www.oopenart.com).

Adott dij ellenében az online közlemények bárki számára hozzáférhetök honlapunkon (a közlemények külön linket kapnak, igy más oldalról is linkelhetővé válnak).

Bővebb információ a hirdetes@akkrt.hu címen vagy különlenyomat rendelése esetén a Szerkesztőségtől kérhető. 